\title{
NIAT PERILAKU PETANI SAWIT SWADAYA DALAM PENINGKATAN USAHA BERKELANJUTAN DI KABUPATEN SAMBAS PROVINSI KALIMANTAN BARAT
}

\author{
Vicki*, Nurliza, Eva Dolorosa \\ *Program Studi Magister Agribisnis, Fakultas Pertanian, Universitas Tanjungpura \\ Jl. Prof. Dr. H. Hadari Nawawi, Pontianak 78124 \\ *Corresponding author: vickidzifa@gmail.com
}

\begin{abstract}
The development of sustainable oil palm plantations as presented in the ISPO (Indonesian Sustainable Palm Oil) frame work is important to be implemented. This study aims to analyze the behavioral intentions of independent small holders in Sambas Regency related to increasing sustainable palm oil business. This study implemented descriptive and inferential analysis by using structural equation modeling (SEM). The results showed that farmers' behavioral intentions are determined by attitudes (general attitudes, personal attitudes, emotional values, and intelligence) and perceptions of behavioral control (experience, knowledge, media, and intervention), which further influence behavior, but subjective norms (age, sex, education, income, and religion) are known not to affect the intention of farmers to behave. In the context of fostering and developing oil palm, farmers began to be fostered to try to work in groups through farmer groups and form cooperatives because ISPO certification will only be given to farmers through farmer groups or cooperatives.
\end{abstract}

Keywords: Indonesian Sustainable Palm Oil (ISPO), sustainability,intention of farmer's behavior, Theory Planned Behavior (TPB)

\begin{abstract}
Abstrak: Pembangunan perkebunan kelapa sawit berkelanjutan sebagaimana tersaji di dalam kerangka ISPO (Indonesian Sustainable Palm Oil) penting untuk dilakukan. Penelitian ini bertujuan untuk menganalisis niat perilaku petani swadaya di Kabupaten Sambas terkait peningkatan usaha berkelanjutan kelapa sawit. Statistik deskriptif dan inferensial diaplikasikan menggunakan stuctural equation modelling (SEM). Hasil penelitian menunjukkan niat perilaku petani ditentukan oleh sikap (sikap umum, sikap pribadi, nilai emosi dan intelegensi) dan persepsi kontrol perilaku (pengalaman, pengetahuan, media, dan intervensi) yang selanjutnya memengaruhi perilaku. Namun norma subjektif (usia, jenis kelamin, pendidikan, pendapatan, dan agama) tidak memengaruhi niat petani untuk berperilaku. Petani sawit perlu diedukasi untuk membentuk kelompok tani atau koperasi karena sertifikasi ISPO hanya dapat dilakukan oleh kelompok tani atau koperasi.
\end{abstract}

Kata kunci: Indonesian Sustainable Palm Oil (ISPO), keberlanjutan, niat perilaku petani, Theory Planned Behavior (TPB)

\section{PENDAHULUAN}

Kelapa sawit adalah komoditas perkebunan unggulan Indonesia yang berkontribusi terhadap kesejahteraan ekonomi masyarakat pedesaan (FOKSBI, 2017). Komoditas tersebut menyumbang 204 triliun untuk pendapatan devisa negaraatau setara 53,56\% dari kontribusi sektor perkebunan (BPS, 2018). Pendapatan devisa ini tidak saja diperoleh melalui perkebunan besar milik swasta dan negara tetapi juga diperoleh dari perkebunan skala kecil atau perkebunan rakyat (Ewaldo, 2015). Produksi industri kelapa sawit Indonesia adalah 
48,68 juta ton, terdiri dari minyak kelapa sawit (crude palm oil/CPO) sebesar 40,57 juta ton dan minyak inti sawit (palm kernel oil/PKO) sebesar 8,11 juta ton. Sebagian besar produksi tersebut dihasilkan oleh perkebunan sawit swadaya sebesar 16,8 juta ton (35\%), disusul oleh perkebunan besar negara sebesar 2,49 juta ton $(5 \%)$, serta perkebunan besar swasta sebesar 29,39 juta ton (60\%). Industri tersebut juga berperan penting dalam pembangunan daerah, menyediakan lapangan pekerjaan dan meningkatkan taraf hidup pekebun (Nurfatriani et al., 2018).

Kontribusi petani sawit swadaya yang relatif besar tersebut mendorong pemerintah Indonesia untuk membuat peraturan Permentan No.11/2015 tentang sistem sertifikasi kelapa sawit berkelanjutan Indonesia / Indonesian Sustainable Palm Oil Certification System (ISPO) dalam rangka pembangunan perkebunan kelapa sawit berkelanjutan. ISPO adalah praktik pembangunan kelapa sawit berkelanjutan yang telah disesuaikan dengan aturan hukum yang berlaku di Indonesia. Peraturan ini diharapkan dapat menjadi bentuk akselerasi agenda pembangunan nasional dan upaya pemerintah dalam mengurangi isu negatif industri kelapa sawit Indonesia (Kospa, 2016). Sertifikasi ISPO menjadi sebuah keharusan bagi pelaku usaha, baik perusahaan maupun petani plasma dan swadaya, dengan pertimbangan bahwa produk hasil TBS (Tandan Buah Segar) petani juga akan menjadi bagian dari mata rantai pasokan pabrik pengolahan minyak sawit (Komisi ISPO, 2014; Nurfatriani et al., 2018).

Perkebunan kelapa sawit (milik rakyat, swasta, dan negara) selain berkontribusi positif terhadap pembangunan ekonomi juga berdampak negatif. Meskipun ada beberapa argumentasi menunjukan bahwa perkebunan tersebut mempunyai dampak negatif. Perluasan perkebunan kelapa sawit skala besar dianggap sebagian pihak berdampak negatif terhadap lingkungan, menjadi penyebab hilangnya keanekaragaman hayati, mengancam keberadaan hutan tropis dan menyebabkan perubahan iklim, dan minyak sawit yang dihasilkannya juga dianggap tidak baik untuk kesehatan (Hidayat, 2016). Alasan tersebut membuat petani sawit swadaya perlu untuk menerapkan praktik budidaya kelapa sawit yang berkelanjutan. Praktik tersebut diharapkan dapat membuat peningkatan daya saing minyak kelapa sawit di pasar global dan kelestarian lingkungan agar petani sawit swadaya mampu bersaing dan tidak menjadi aktor yang selalu dirugikan dalam rantai pasok industri ini.

Tuntutan sertifikasi ISPO untuk menjaga pembangunan kelapa sawit yang selaras dengan tujuan ekonomi, sosial budaya pelestarian lingkungan, mengharuskan petani sawit swadaya untuk melakukan pengembangan perkebunan kelapa sawit berkelanjutan semakin besar (Lestari et al., 2015). Penelitian empiris Hutabarat (2017) menyatakan bahwa sebagian besar petani kelapa sawit swadaya masih menerapkan budidaya konvensional. Hal tersebut membuat penerapan pertanian berkelanjutan seperti praktik budidaya yang baik (Good Agricultural Practice/GAP) dan praktik pengelolaan yang baik (Best Management Practices/BMP) khususnya terkait penggunaan bibit unggul, pupuk, pengendalian organisme pengganggu tanaman (OPT),serta penanganan panen dan pasca panen (Lestari et al., 2015; Rokky et al., 2015).

Berbagai masalah yang dikedepankan dari hadirnya kelapa sawit swadaya yaitu produktifitas yang relatif rendah bila dibanding dengan perusahaan besar, terbatasnya modal dan keterampilan, posisi tawar petani yang masih rendah dalam hal penentuan harga buah, lahan banyak yang belum memiliki sertifikat legal, kurangnya peranan dari KUD dan kelompok tani dan kurangnya perhatian kelestarian lingkungan (Prasetia, 2017). Berdasarkan kondisi tersebut ada kecenderungan bahwa kelapa sawit swadaya sulit memenuhi syarat perkebunan yang berkelanjutan sesuai ISPO (Indonesian sustainable palm oil) (Arif, 2016). Petani adalah faktor penentu budidaya kelapa sawit berkelanjutan (Hidayat, 2016). Petani mempunyai hambatan terkait jangkauan permodalan, teknologi informasi yang menghambat budidaya kelapa sawit yang berkelanjutan. Melihat kondisi ini peneliti ingin mengkaji bagaimana respon atau reaksi (perilaku) petani sawit swadaya di Kabupaten Sambas terhadap upaya peningkatan usaha berkelanjutan sebagaimana yang tersaji dalam kerangka ISPO. 
Petani sebagai aktor utama pembangunan pertanian mempunyai beberapa peran yang berhubungan langsung dalam keberhasilan pembangunan pertanian yaitu sebagai juru tani, pengelola usaha tani, serta sebagai bagian dari sistem sosial masyarakat (Astuti, 2016). Niat perilaku petani dalam kegiatan usahatani dapat diukur dari berbagai cara pandang. Penelitian ini menggunakan perspektif Theory Planned Behavior (teori perilaku yang direncanakan) untuk memahami niat perilaku petani sawit swadaya terkait peningkatan usaha berkelanjutan. Teori ini berasumsi bahwa perilaku individu dipengaruhi oleh niat individu tersebut. Niat adalah dorongan yang menentukan perilaku yang tergantung pada keyakinan yang menghubungkan perilaku yang ditunjukan dengan hasil (sikap) tertentu, tekanan sosial untuk melakukan sesuatu (norma subyektif). Niat diasumsikan memengaruhi kinerja perilaku sepanjang individu tersebut dapat mengendalikan perilakunya (Ajzen, 1991). Teori tersebut menunjukkan bahwa niat perilaku petani dan determinan perilaku tersebut sebelum tindakan dapat diamati, dan memiliki implikasi penting untuk kebijakan pertanian dan strategi industry (Läpple dan Kelley, 2013).

TPB (Theory Planned Behavior) merupakan model psikologi sosial yang menunjukkan bahwa kinerja perilaku tertentu terutama ditentukan oleh niat individu untuk berperilaku sedemikian rupa (Ajzen, 1991). Merujuk kepada perspektif TPB (Theory Planned Behavior) tersebut maka penelitian ini bertujuan untuk menganalisis niat perilaku petani sawit swadaya di Kabupaten Sambas terkait peningkatan usaha berkelanjutan sebagaimana tersaji dalam kerangka ISPO dalam mewujudkan produksi kelapa sawit yang berkelanjutan.

\section{METODE PENELITIAN}

Penelitian dilakukan di Kecamatan Subah, Tebas, dan Sejangkung Kabupaten Sambas. Populasi responden adalah semua petani sawit swadaya yaitu $8.719 \mathrm{KK}$ (Kartu Keluarga) yang tersebar di wilayah Kabupaten Sambas(BPS, 2017). Penelitian ini mengambil responden di 3 (tiga) kecamatan yang mempunyai jumlah petani sawit swadaya terbesar di Kabupaten
Sambas yaitu Kecamatan Subah sebanyak 4.921 KK, Kecamatan Tebas sebanyak 1.190 KK, dan Kecamatan Sebawi sebanyak 1.021 KK (BPS, 2017). Penentuan sampel menggunakan metode Stratified Random Sampling, pada tiap kecamatan masing-masing diambil responden sesuai dengan proporsi persentase jumlah petani sawit di setiap kecamatan sehingga untuk Kecamatan Subah diambil sampel sebanyak 103 sampel, Kecamatan Sebawi 22 sampel dan 25 sampel di Kecamatan Tebas. Data diperoleh melalui wawancara dan kuesioner yang memiliki tingkat pengembalian yang tinggi dan membutuhkan lebih sedikit jawaban, dengan urutan jawaban terkontrol, praktis dan relatif fleksibel (Alshenqeeti, 2014). Pengolahan data dilakukan menggunakan Microsoft Office Excel 2007 dan Software Lisrel versi 8.54. Data dianalisis menggunakan SEM (Structural Equation Model) dengan pendekatan statistik deskriptif dan inferensial.

\section{HASIL DAN PEMBAHASAN}

\section{Karakteristik Usahatani Kelapa Sawit}

Karakteristik usahatani kelapa sawit adalah unsur yang sumbernya dari eksternal diri responden dan berhubungan dengan pengelolaan usahatani kelapa sawit yang dapat mendukung kegiatan usahatani seperti yang tersaji pada Tabel 1 .

Status kepemilikan lahan adalah pengakuan hak atas tanah yang diakui secara hukum dalam bentuk bukti tertulis berupa sertifikat yang dikeluarkan dan disahkan oleh Badan Pertanahan Nasional (BPN). Status kepemilikan lahan petani di Kabupaten Sambas 100 persen adalah milik pribadi. Rata-rata petani sawit swadaya mempunyai luas lahan dibawah 4 ha. Lahan merupakan salah satu faktor produksi yang berperan dalam kegiatan usahatani. Luas lahan berpengaruh terhadap tingkat produksi usahatani (Kurniawan, 2014).

Petani relatif melakukan panen tiap minggu sekali atau 4 kali sebulan. Harga jual TBS ditingkat petani cukup fluktuatif yaitu berkisar antara Rp1.000-Rp.1.200 per kg. Harga jual sawit ditingkat petani bervariasi karena saluran pemasaran yang mereka pilih dan jarak lokasi pabrik dengan kebun petani berbeda-beda. 
Vicki, Nurliza, Dolorosa, E. : Niat Perilaku Petani Sawit Swadaya ...

Tabel 1. Karakteristik usahatani kelapa sawit di Kabupaten Sambas

\begin{tabular}{|c|c|c|}
\hline Karakteristik Usahatani & Frekuensi (Orang) & Presentase $(\%)$ \\
\hline \multicolumn{3}{|l|}{ Status Kepemilikan Lahan } \\
\hline Sertifikat Hak Milik & 150 & 100 \\
\hline \multicolumn{3}{|l|}{ Luas Kepemilikan Kebun } \\
\hline$\leq 4$ ha & 108 & 72 \\
\hline $5-8$ ha & 30 & 20 \\
\hline$\geq 9$ ha & 12 & 8 \\
\hline \multicolumn{3}{|l|}{ Panen Kebun Sawit } \\
\hline 2 kali perbulan & 37 & 25 \\
\hline 4 kali perbulan & 113 & 75 \\
\hline \multicolumn{3}{|l|}{ Harga Jual TBS } \\
\hline $\mathrm{Rp} 1.000 / \mathrm{kg}$ & 50 & 33 \\
\hline $\mathrm{Rp} 1.100 / \mathrm{kg}$ & 20 & 13 \\
\hline $\mathrm{Rp} 1.200 / \mathrm{kg}$ & 80 & 53 \\
\hline \multicolumn{3}{|l|}{ Lokasi Penjualan TBS } \\
\hline Pabrik & 150 & 100 \\
\hline \multicolumn{3}{|l|}{ Jarak Kebun Sawit ke Pabrik } \\
\hline$\leq 2 \mathrm{~km}$ & 100 & 67 \\
\hline$\leq 2,1-4 \mathrm{~km}$ & 35 & 23 \\
\hline$\geq 4,1 \mathrm{~km}$ & 15 & 10 \\
\hline \multicolumn{3}{|l|}{ Pengalaman Usahatani } \\
\hline$\leq 10$ tahun & 98 & 66 \\
\hline $11-20$ tahun & 28 & 19 \\
\hline$\geq 21$ tahun & 24 & 16 \\
\hline
\end{tabular}

Sumber: Analis Data Primer, 2019

Jauh dekatnya lokasi kebun dengan pabrik pengolahan kelapa sawit sangat memengaruhi harga TBS di tingkat petani (Mawardati, 2016). Semua petani yang dijadikan responden yang berasal dari Kecamatan Subah, Tebas dan Sebawi menjual TBS mereka langsung ke pabrik. Jarak antara kebun sawit ke pabrik kurang lebih $4 \mathrm{~km}$. Jarak ini relatif dekat karena kebun petani berada disekitar pabrik CPO. Petani swadaya sawit umumnya mempunyai pengalaman sekitar 10 tahun dalam berusahatani. Pengalaman usahatani yang relatif lama berkorelasi positif terhadap pengetahuan, keterampilan, serta sikap petani terhadap adopsi inovasi pertanian (Alfayanti dan Efendi, 2013).

\section{Niat Perilaku Petani Sawit Swadaya Terkait Peningkatan Usaha Berkelanjutan}

TPB (Theory Planned Behavior) pada penelitian ini memberikan kerangka teoritis terbatas untuk memahami keyakinan dan motivasi petani dan bagaimana informasi dapat memengaruhi niat perilaku petani. Peran sikap individu, tekanan sosial dan kontrol atas perilaku dapat dievaluasi dan dinilai untuk memahami apa yang mendorong petani untuk bersifat rasional dan terlebih dahulu akan mempertimbangkan implikasi dan kosekuensi dari perilakunya sebelum membuat keputusan untuk melakukannya sehingga mampu meningkatkan daya saing dan memenuhi keberlanjutan industri kelapa sawit yang lestari. Hasil penelitian terkait niat perilaku petani sawit swadaya di Kabupaten Sambas tersaji pada Gambar 1.

Persamaan struktural (structural equation) t-value menunjukkan besarnya pengaruh antara variabel laten bebas terhadap variabel laten terikat. Dan Nilai koefisien estimasi regresi menunjukkan tingkat kontribusi variabel laten bebas terhadap variabel laten terikat. Nilai $\mathrm{R}^{2}$ yang diperoleh pada persamaan model struktural adalah sebesar 0,67 artinya bahwa sebesar $67 \%$ niat perilaku petani ditentukan oleh variabel yang ada digunakan dalam penelitian ini, sedangkan sisanya (33\%) dipengaruhi oleh faktor lainnya di luar variabel penelitian ini. Gambar 1 menunjukkan bahwa prediktor terbaik terkait niat perilaku petani sawit swadaya dari ketiga variabel penentu niat perilaku adalah sikap dan persepsi kontrol perilaku. 


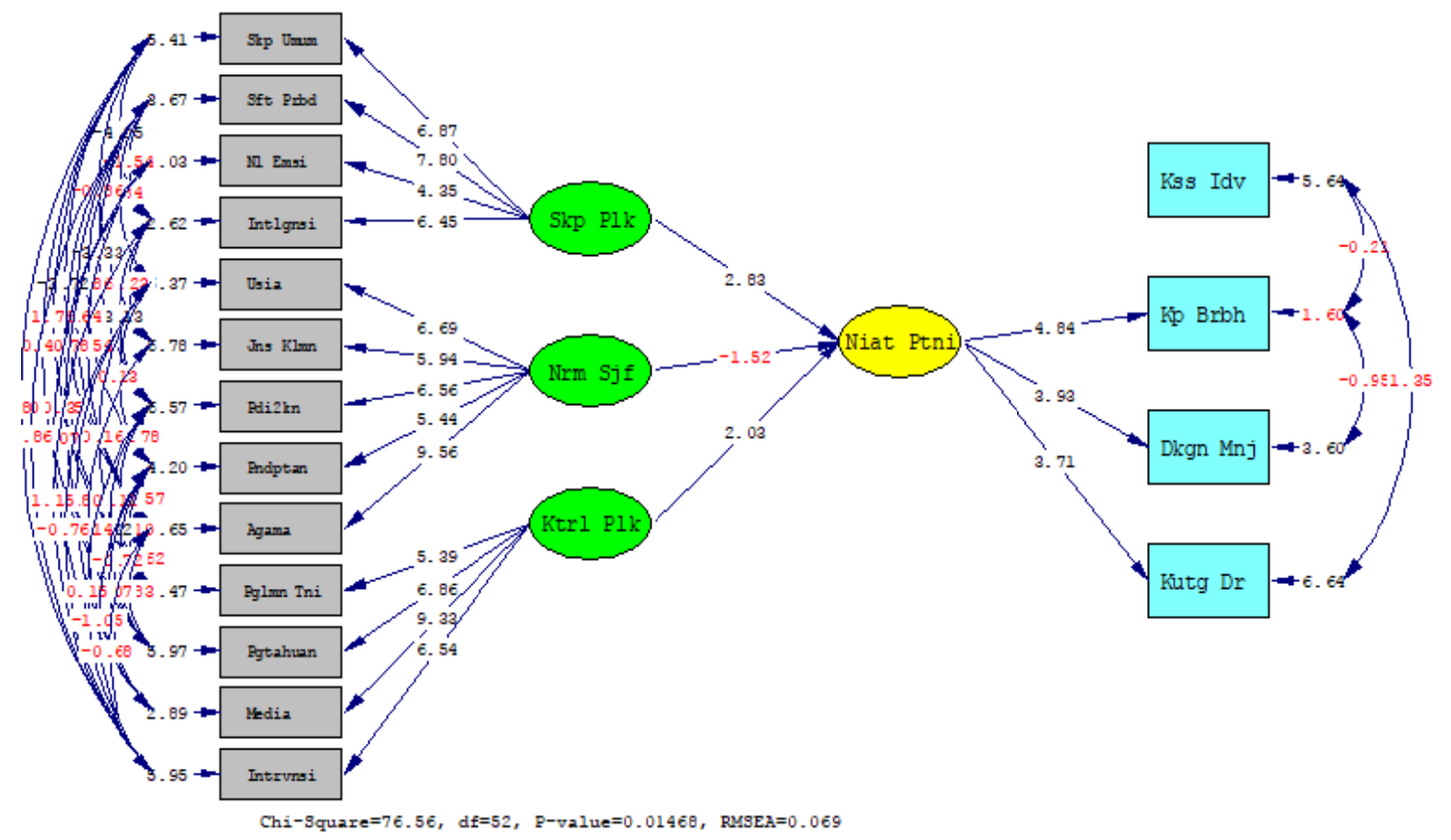

a) t-value

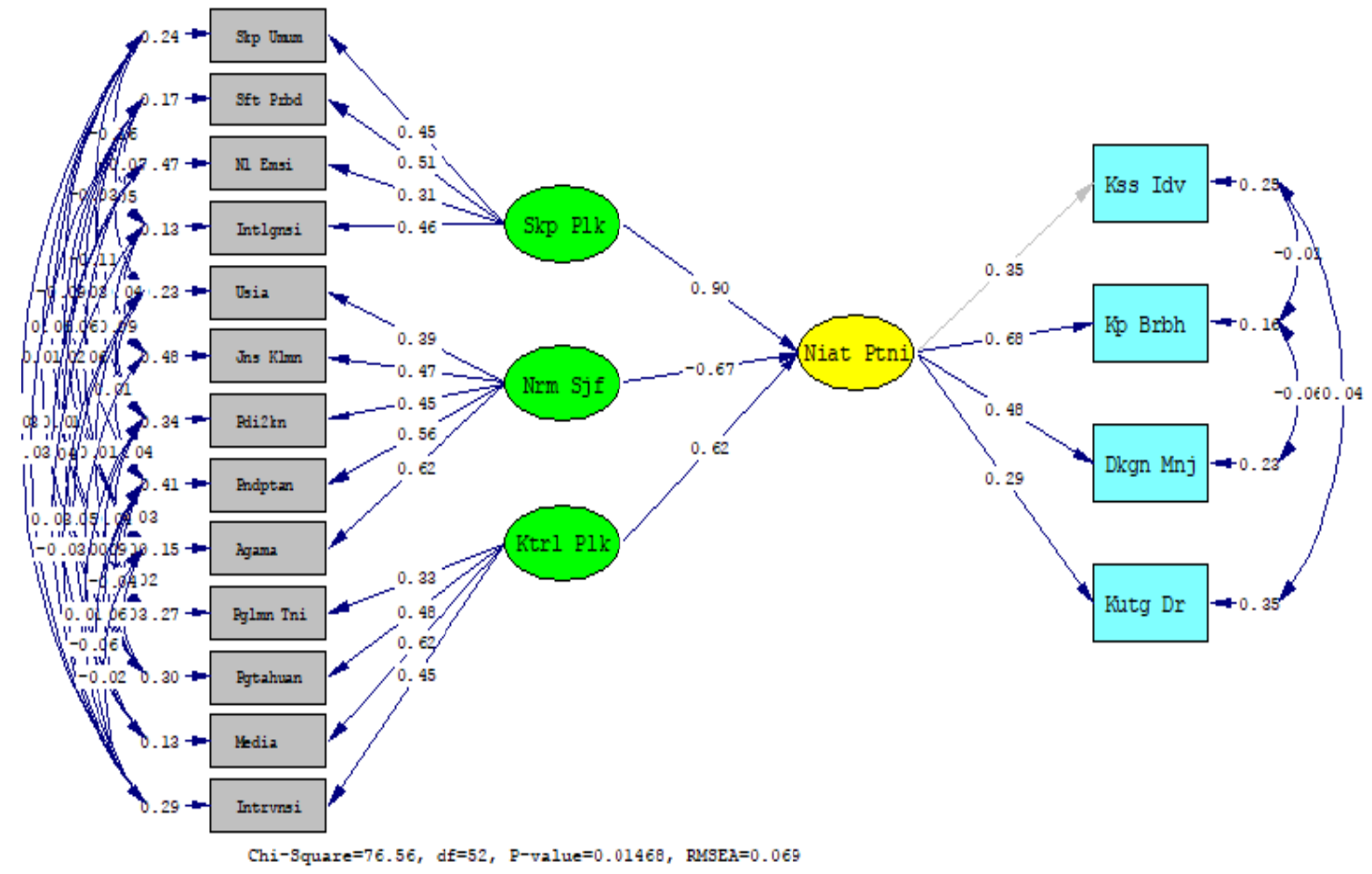

b) Koefisien Estimasi

Gambar 1.a) t-value dan b) Koefisien Estimasi Model TPB Perilaku Petani Sumber: Analisis Data Primer, 2019

Pada dasarnya petani sawit swadaya di Kabupaten Sambas telah siap menghadapi upaya peningkatan usaha berkelanjutan dalam mewujudkan produksi kelapa sawit yang berkelanjutan. Namun, variabel norma subyektif masih menjadi kendala yang menghambat niat perilaku petani dalam upaya peningkatan usaha berkelanjutan sawit. Hal 
tersebut ditunjukkan oleh nilai variabel tersebut yang tidak signifikan. Hasil tersebut bertentangan dengan pendapat Ajzen (1991) bahwa faktor pembentuk keyakinan normatif dalam pembentukan norma subyektif individu seperti umur, pendapatan, jenis kelamin, pendidikan, pengalaman, serta pengetahuan akan memengaruhi perilaku individu tersebut.

\section{Pengaruh Sikap Berperilaku terhadap Niat Perilaku Petani}

Sikap adalah hasil stimulus atau reaksi yang berasal dari internal individu terhadap lingkungan, serta bentuk antisipasi berupa tindakan yang membentuk perilaku (Astuti, 2016; Nurmastiti et al., 2017). Gambar 1 menjelaskan bahwa sikap signifikan terhadap niat berperilaku petani. Hal ini berarti bahwa peningkatan $1 \%$ sikap berperilaku akan signifikan terhadap niat berperilaku petani sebesar $0,90 \%$. Sikap terhadap perilaku petani ini mengindikasi bahwa sebagian besar petani mempunyai niat yang sangat besar untuk perilaku terkait peningkatan usaha berkelanjutan perkebunan kelapa sawit.

Harianja et al., (2015) menyatakan bahwa sikap seseorang bergantung pada ekspetasi seseorang terhadap suatu objek. Objek yang berdampak positif akan cenderung diterima masyarakat dan sebaliknya. Hal ini juga berlaku dalam hal sikap suatu individu. Individu akan berperilaku sesuai sikap yang dimilikinya. Individu cenderung akan berperilaku dengan sikap yang positif. Oleh karena itu, sikap adalah cara terbaik untuk membentuk individu dalam berperilaku (Indra, 2017).

Gambar 1 menunjukkan sikap umum, sifat pribadi, nilai emosi dan intelegensi berkontribusi pada sikap petani artinya indikator-indikator ini berpengaruh positif terhadap niat petani untuk berperilaku. Sikap umum menjelaskan tentang sikap petani terhadap lingkungan sudah baik dengan adanya respon petani dalam meningkatkan kesinambungan produksi dan kelestarian sumber daya alam serta kekhawatiran akan dampak dari kerusakan alam saat ini dan yang akan datang. Masyarakat seharusnya mempunyai perilaku yang menjunjung tinggi kelestarian alam karena sikap tersebut berdampak positif terhadap kelangsungan ekologi (Suki, 2013; Suryandari et al., 2016).

Sifat pribadi menunjukan adanya kesadaran petani untuk mengelola pertanian dengan memperhatikan aspek kelestarian ekologi dan penerapan fungsi kelompok tani secara optimal. Kesadaran ekologi adalah keadaan termotivasi untuk menjaga kelestarian lingkungan dalam bentuk niat dan perilaku individu (Neolaka, 2008; Irianto dan Haryanto, 2011; Jaolis, 2011). Petani juga telah merasakan adanya manfaat dari yang mereka terima ketika berpartisipasi secara aktif dalam kelompok tani dimana petani mendapat pinjaman pupuk yang pengembaliannya mereka diberi pilihan dengan mencicil lewat hasil panen mereka. Petani bukan hanya mendapat manfaat ekonomi saja tetapi manfaat sosial seperti kekeluargaan yang lebih erat dan manfaat psikologis seperti para petani merasakan kehadirannya berguna bagi kelompok sehingga meningkatkan daya saing dan perlindungan lingkungan serta membangun strategi berdasarkan karakteristik regional dan proses sosial akan menghasilkan keberlanjutan (OECD et al., 2014; Puspitaningsih et al., 2016).

Nilai emosi menjelaskan tentang penyesuaian internal individu yang didasari pengalaman afektif terkait psikologis dan fisik, serta terlihat dalam bentuk tingkah laku berupa keterlibatan petani dalam berorganisasi dan peran petani untuk merealisasikan perkebunan kelapa sawit yang berkelanjutan. Petani swadaya yang berpartisipasi dalam suatu organisasi petanian akan memperoleh manfaat dari rantai nilai jika terkoordinasi dan didukung oleh masyarakat dengan mempertimbangkan relevansi model organisasi petani, yaitu mulai dari situasi dimana petani berpartisipasi dalam bentuk struktur informal atau formal yang terorganisir dan petani diharapkan memberikan manfaat sebagai wadah dalam memfasilitasi dan menjembatani berbagai aspirasi kepentingan petani dan stakeholders baik pemerintah maupun swasta (Nurliza, 2018). Kelembagaan sebagai indikator keberlanjutan perkebunan kelapa sawit merupakan aspek yang berpengaruh langsung terhadap produktivitas usahatani (Komisi ISPO, 2014). Kelembagaan masih menjadi persoalan yang dihadapi oleh sebagian besar kelompok tani di 
Indonesia dan menjadi hambatan untuk menjalankan perkebunan yang berkelanjutan. Banyak koperasi yang tidak sehat dan menjadi awal dari buruknya praktik pengelolaan perkebunan kelapa sawit yang bermuara pada rendahnya produktivitas lahan dan kemiskinan petani. Oleh sebab itu, penguatan kelembagaan petani merupakan langkah awal untuk dapat meningkatkan pendapatan petani kelapa sawit. Intelegensi menjelaskan tentang kemampuan petani untuk berkomunikasi dan berinteraksi dengan orang lain, dimana petani mampu melakukan kemitraan dengan pihak lain dan menentukan pasar untuk hasil tani, petani memiliki posisi dan peran petani dalam keberlanjutan ditentukan oleh tingkat partisipasi petani dalam kelompok tani, dan komunikasi petani melalui koordinasi lintas institusi baik internal maupun eksternal melalui forum dialog dan pertukaran informasi tentang usaha berkelanjutan sawit. Pengaruh positif yang ditimbulkan oleh faktor intelegensi pada dimensi sikap pada perilaku terhadap niat untuk berperilaku karena adanya kemampuan petani dalam berkomunikasi dan berinteraksi dengan orang lain. Intelegensi berhubungan dengan tingkat kemampuan untuk menganalisis nilai manfaat dari berbagai aspek, seperti produksi, kebutuhan pasar, kemampuan usahatani, pendapatan dalam mendukung keberlanjutan lahan usahatani (Suharyanto et al., 2017). Petani mempunyai kemampuan dalam menentukan pasar potensial untuk menjual hasil usaha tani kelapa sawit seperti pengepul yang membeli dengan harga tinggi (Pratama et al., 2015).

\section{Pengaruh Norma Subyektif terhadap Niat Berperilaku Petani}

Norma subyektif merupakan presepsi individu untuk memberikan reaksi perilaku terhadap tekanan sosial yang dihadapi. Variabel norma subyektif berdampak tidak langsung terhadap niat petani untuk berperilaku, sedangkan indikator norma subyektif terdiri dari umur, jenis kelamin, tingkat pendidikan, agama, serta pendapatan berpengaruh signifikan terhadap norma subyektif. Hal ini menunjukkan bahwa norma subyektif adalah variabel yang tidak signifikan terhadap niat berperilaku. Penelitian empiris George (2004) menyatakan tidak ada hubungan perilaku dengan norma subjektif walaupun terdapat hubungan signifikan dari struktur normatif dengan norma subjektif karena variabel semacam ini mengacu pada keyakinan yang mendasari sikap dan sosial dalam menerima berbagai tekanan sosial terkait prefensi melaksanakan suatu perilaku (Bahua et al., 2010). Hal ini berlawanan dengan penelitian Prihandoko et al. (2012) yang menyatakan bahwa dalam kaidah theory planned behavior, karakteristik demografi signifikan terhadap keyakinan berperilaku, sikap, serta norma subjektif dipengaruhi karakteristik demografi dan memengaruhi tetapi niat individu untuk berperilaku.

Usia merupakan indikator dalam menentukan produktif atau tidaknya seseorang, cara berpikir dan kemampuan fisik dalam menjalankan usahatani. Usia petani di Kabupaten Sambas berkisar antara 31-60 tahun yang berada pada kelompok kerja produktif, sehingga berpotensi untuk meningkatkan produksi dan pengembangan usahataninya melalui pengembangan diri dan upaya lainnya dalam meningkatkan kinerja petani dapat dilaksanakan dengan baik dan lancar (Muttakin et al., 2014). Petani yang berumur muda bekerja lebih kuat lebih dinamis dan tanggap terhadap lingkungan sekitar terutama yang berhubungan dengan keberlanjutan usahataninya. Petani yang mempunyai umur lebih muda biasanya relatif agresif dalam pengambilan keputusan dan lebih mau menerima inovasi baru serta lebih berani dalam mengambil risiko (Hasyim, 2006).

Jenis kelamin petani sawit di Kabupaten Sambas sebagian besar didominasi laki-laki. Hal tersebut karena laki-laki merupakan aktor utama dalam mencari nafkah bagi keluarga. Pengetahuan yang dimiliki laki-laki dalam hal usahatani lebih banyak dan aktif dari pada perempuan dikarenakan keterlibatan laki-laki dalam kegiatan kelembagaan pertanian seperti penyuluhan pertanian dalam kelompok tani. Pengetahuan tersebut dapat terkait dengan sarana produksi usahatani, teknik budidaya, askes pasar produk pasca panen (Yuwono, 2013). Laki-laki juga lebih banyak terlibat dalam program pembangunan pertanian di tingkat desa (Hastuti, 2004).

Pendidikan adalah salah satu faktor pelancar pembangunan pertanian yang berkelanjutan. Keterbatasan pendidikan yang 
dimiliki petani dapat menjadi dapat menjadi kendala dalam usaha keberlanjutan yaitu terhadap cara berpikir serta mengambil keputusan. Petani dengan pendidikan relatif tinggi akan berpikir lebih rasional dibanding petani dengan pendidikan rendah. Petani Sawit swadaya di Kabupaten Sambas sebagian besar mengenyam pendidikan 1-9 tahun, dan ini menunjukan bahwa tingkat pendidikan masih rendah. Hal tersebut berpengaruh terhadap adopsi teknologi yang relatif lambat, padahal pengembangan usahatani memerlukan teknologi (Muttakin et al., 2014; Nurmastiti et al., 2017).

Pendapatan signifikan terhadap norma subyektif karena industri kelapa sawit mempunyai peluang yang relatif tinggi sebagai sumber pendapatan petani untuk mendukung peningkatan kesejahteraan petani. Peningkatan kesejahteraan rakyat sebagai indikator kebermanfaatan usaha tani kelapa sawit dapat tercapai melalui perbaikan harga jual dan peningkatan produktivitas (Muttakin et al., 2014). Oleh karena itu, perlu dukungan koperasi dalam pengembangan kelapa sawit dan tugas petani dalam menjaga kualitas buah yang baik agar sesuai dengan keinginan pasar (Kospa, 2016).

Agama signifikan terhadap norma subyektif karena agama telah dihidupi oleh masyarakat dalam kehidupan sehari-hari sebagai bentuk keyakinan terhadap hal Supernatural dan nilai kehidupan setiap individu untuk menjaga hubungan antar anggota masyarakat. Oleh karena itu, agama secara psikologis berfungsi sebagai motif intrinsik (dalam diri) maupun ekstrinsik (luar diri) untuk berperilaku dalam masyarakat (Anam, 2016). Komitmen keagamaan dapat membantu membangun (misalnya, kesadaran, kesesuaian,dan pengendalian diri), juga dapat memperlengkapi orang untuk mengadopsi yang relevan dengan perilaku di kemudian hari, bahkan jika perilaku yang berhubungan itu kembali tidak ada dukungan normatif khusus dari dalam sistem agama mereka (McCullough et al., 2009).

Dampak langsung norma subjektif terhadap niat yaitu individu menjadi melakukan suatu perilaku tanpa menyukai hal tersebut (Venkatesh dan Davis, 2000). Faktor-faktor yang dapat memengaruhi asal usul perilaku seseorang juga merangsang sejumlah besar penelitian untuk menunjuk faktor latar belakang pribadi seperti usia, pendapatan atau pendidikan sebagai predisposisi individu terhadap perilaku aktual pada masalah lingkungan (Bamberg, 2013). Pembangunan perkebunan kelapa sawit berkelanjutan diharapkan tidak hanya memiliki produktivitas dan stabilitas yang tinggi, tetapi juga mengedepankan rasa kesetaraan dan nilai-nilai kearifan lokal yang tinggi terhadap lingkungan (Kospa, 2016).

\section{Pengaruh Persepsi Kontrol Perilaku terhadap Niat Berperilaku Petani}

Persepsi kontrol perilaku terbentuk dari persepsi individu terhadap suatu perilaku yang diyakininya merupakan hasil keinginannya sendiri (Suryandari et al., 2016). Persepsi kontrol perilaku signifikan terhadap niat berperilaku petani dengan loading factor sebesar 0,62 . Peningkatan $1 \%$ nilai persepsi kontrol perilaku signifikan terhadap niat berperilaku petani sebesar 62\%. Ini menjelaskan bahwa persepsi kontrol perilaku signifikan terhadap niat berperilaku petani. Persepsi kontrol perilaku petani ini mengindikasi bahwa sebagian besar petani mempunyai niat yang besar untuk perilaku terkait peningkatan usaha berkelanjutan perkebunan kelapa sawit.

Pengalaman bertani berkontribusi pada persepsi kontrol perilaku artinya indikator ini signifikan terhadap niat petani untuk berperilaku menjelaskan tentang lamanya waktu yang telah atau sedang digunakan untuk usahatani kelapa sawit. Pengalaman bertani berhubungan positif terhadap peningkatan kompetensi petani. Tingkat pengalaman yang relatif tinggi membuat petani relatif lebih matang dalam mengambil keputusan usahatani terutama terkait alternatif terbaik dalam upaya peningkatan produktivitas.

Pengalaman adalah kumpulan pengetahuan dan keterampilan yang didapat melalui rutinitas kegiatan. Petani yang sudah lama mempunyai pengalaman usahatani cenderung mengalami kegagalan yang kecil dan akan mudah mengatasi masalah yang akan terjadi, karena telah mengetahui dan menguasai lingkungan usahataninya sehingga dapat meningkatkan usaha keberlanjutan kelapa sawit 
yang dimilikinya (Bahua et al., 2010; Muttakin et al., 2014). Pengalaman pribadi akan menjadi dasar pembentukan perilaku, jika pengalaman tersebut terkait langsung dengan faktor emosional yang berkesan bagi pribadi tersebut (Asih dan Pratiwi, 2010).

Pengetahuan adalah kemampuan intelegensi petani dalam menguasai materi yang dipelajarinya. Pengetahuan signifikan terhadap niat berperilaku petani karena pengetahuan berkontribusi terhadap persepsi dan penentuan kontrol perilaku. Hal tersebut juga menjelaskan bahwa pengetahuan petani tentang praktik berkelanjutan terkait aplikasi pemupukan, pestisida, pola perawatan, dan good handling practies (GHP) kelapa sawit menjadi salah satu indikator kontrol perilaku. Pengelolaan kebun dengan praktik yang baik disadari oleh petani dapat kualitas dan produktivitas kebun kelapa sawit, serta secara tidak langsung meningkatkan keuntungan ekonomi petani. Pengetahuan tersebut dapat mendorong perubahan positif perilaku petani dan menjadi dasar adopsi inovasi (Sormin, 2012; Wilson, 2012).

Media seperti televisi dan radio adalah sarana komunikasi yang membentuk opini dan kepercayaan masyarakat signifikan terhadap niat berperilaku petani karena media berkontribusi terhadap persepsian kontrol perilaku seseorang. Pembentukan kontrol suatu hal dapat terbentuk karena adanya landasan kognitif baru dari pemberian informasi baru oleh media. Intensitas interaksi baik melalui media interpersonal, media kelompok, maupun media massa akan mendukung dan memudahkan alur diseminasi penyebaran inovasi sehingga suatu teknologi baru dapat diterima dan diaplikasikan dengan baik oleh pengguna teknologi (Sasongko et al., 2014). Pesan sugestif dari informasi membentuk perilaku melalui pembentukan dasar afektif berupa menilai atau mempersepsikan suatu hal. Akses petani swadaya terkait akses informasi, input, finansial, dan pasar dapat memengaruhi kinerja usaha petani swadaya sawit dalam peningkatan keberlanjutan usahatani.

Teknologi komunikasi dan informasi telah memberikan kemudahan komunikasi peertanian dan sistem informasi pertanian, khususnya media komunikasi inovasi pertanian (Mulyandari, 2011; Suki, 2013). Teknologi tersebut berdampak terhadap percepatan informasi dalam sistem penyuluhan pertanian, serta perbaikan kualitas dan produktivitas produksi melalui memperbaiki kecepatan akses petani terhadap informasi dan tren pasar maupun input produksi pertanian (Amin, 2014; Prayoga, 2018).

Intervensi adalah keterlibatan pihak luar terhadap masalah individu. Intervensi terjadi pada peran kelompok tani untuk mengevaluasi kegiatan bersama dan interaksi kelompok yang terstruktur yakni adanya peranan produsen dan pedagang dan instansi terkait dalam pelaksanaan standarisasi mutu sesuai dengan fungsinya masing-masing. Oleh karena itu, keterlibatan lembaga pertanian seperti kelompok tani, pemerintah, dan penyuluh pertanian diperlukan untuk membantu petani peningkatan akses pasar domestik dan global, serta akses sarana produksi pertanian organik seperti pupuk dan pembasmi hama organik. Hal tersebut diharapkan dapat mendorong pertanian berkelanjutan melalui peningkatan keuntungan dari penerapan pertanian organik (Permatasari et al., 2018). Pemerintah sebagai lembaga yang memiliki otoritas yang sangat luas dan tinggi, memegang peranan yang penting dalam menggiring pekebun swadaya menuju sistem produksi kelapa sawit yang lestari dan berkelanjutan. Pemerintah dapat menciptakan kondisi yang kondusif melalui peraturan perundangan-undangan untuk memfasilitasi semua aktor-aktor dalam rantai pasok kelapa sawit untuk bersinergi mengkoordinasikan pasar yang efektif dan efisien agar produk kelapa sawit dari Indonesia tetap kompetitif dan diakui di pasar internasional (Hidayat, 2016).

\section{KESIMPULAN}

Niat petani ditentukan oleh sikap (sikap umum, sikap pribadi, nilai emosi dan intelegensi) dan persepsi kontrol perilaku (pengalaman, pengetahuan, media, dan intervensi) yang selanjutnya memengaruhi perilaku, namun norma subjektif (usia, jenis kelamin, pendidikan, pendapatan, dan agama) diketahui tidak memengaruhi niat petani untuk berperilaku. Petani sawit swadaya pada umumnya mengusahakan secara mandiri usahataninya, belum tergabung dalam 
kelompok tani maupun koperasi. Oleh karena itu, perlu edukasi tentang kelompok tani atau koperasi sebagai syarat sertifikasi ISPO melalui sosialisasi manfaat, penyuluhan secara intensif, serta reference group sebagai percontohan. Lembaga pemerintah di tingkat daerah juga perlu terlibat melalui pelaksanaan peraturan perundang-undangan khususnya terkait dokumen legalitas kebun kelapa sawit dengan baik.

\section{DAFTAR PUSTAKA}

Ajzen, I. (1991). The theory of planned behavior. Organizational Behavior and Human Decision Processes, 50(2), 179211.

Alfayanti,\& Efendi, Z. (2013). Analisis faktorfaktor yang memengaruhi produksi kelapa sawit rakyat di Kabupaten Mukomuko. AGRISEP, 13(1), 1-10.

Alshenqeeti, H. (2014). Interviewing as a data collection Method: A critical review. English Linguistics Research, 3(1), 3945.

Amin, M. (2014). Efektivitas dan perilaku petani dalam memanfaatkan teknologi informasi berbasis cyber extension. Jurnal Informatika Pertanian, 23(2), 211-219.

Anam, C. (2016). Pengaruh komitmen beragama, pengetahuan agama, dan orientasi agama terhadap preferensi masyarakat pada bank syariah di Surabaya. Jurnal Studi Manajemen dan Bisnis, 3(1), 80-89.

Arif, J. (2016). Jurisdictional certification approach to support sustainable palm oil production.Retrieved from https:// earthinnovation.org/wp-content/uploads2016/01/Jurisdictional-CertificationApproach-to-Support-Sustainable-PalmOil-Production-.pdf.

Armitage, C. J., \& Corner, M. (2010). Efficacy of the theory of Planned Behavior: A meta-analytic review. British Journal of Social Psychology, 40, 471-499.
Asih, G. Y., \& Pratiwi, M. M. (2010). Perilaku prososial ditinjau dari empati dan kematangan emosi. Jurnal Psikologi Universitas Muria Kudus, 1(1), 33-42.

Astuti, N. B. (2016). Sikap petani terhadap profesi petani: upaya untuk memahami petani melalui pendekatan psikologi sosial (kasus petani di Kecamatan Pauh, Kota Padang). Jurnal AGRISEP, 16(1), $59-66$.

Bahua, M. I., Jahi, A., Asngari, P. S., Saleh, A., \& Purnaba, I. g. (2010). Faktor-faktor yang memengaruhi kinerja penyuluhan pertanian dan dampaknya pada perilaku petani jagung di Provinsi Gorontalo. Jurnal Ilmiah Agropolitan, 3(1), 293303.

Bamberg, S. (2013). How does environmental concern influence specific environmentally related behaviors? A new answer to an old question. Journal of Environmental Psychology, 23, 21-32.

BPS. (2017). Data Statistik Dinas Perkebunan Provinsi Kalimantan Barat. Pontianak: BPS Indonesia.

BPS. (2018). Pusat Data dan Sistem Informasi Pertanian, Kementerian Pertanian. Jakarta: Badan Pusat Statistik Indonesia.

Ewaldo, E. (2015). Analisis ekspor kelapa minyak sawit di Indonesia. E-Jurnal Perdagangan Industri dan Moneter, 3(1), 10-15.

FOKSBI. (2017). Rencana aksi nasional kelapa sawit berkelanjutan2018-2023.Retrieved form http://foksbi.id/id/kegiatan.

George, J. F. (2004). The theory of planned behavior and internet purchasing. Journal of Internet Research, 14(3), 198-212.

Harianja, K., Hutabarat, S., \& Dewi, N. (2015). Analisis persepsi petani kelapa sawit pola swadaya menghadapi sertifikasi RSPO di Kecamatan Ukui Kabupaten Pelalawan. JOM Faperta, 2(1), 1-13. 
Hastuti, E. L. (2004). Pemberdayaan petani dan kelembagaan lokal dalam perspektif gender.Working PaperPusat Penelitian dan Pengembangan Sosial Ekonomi Pertanian.

Hasyim, H. (2006). Analisis hubungan karakteristik petani kopi terhadap pendapatan (studi kasus: Desa Dolok Seribu Kecamatan Paguran Kabupaten Tapanuli Utara). Jurnal Komunikasi Penelitian, 18(1), 22-27.

Hidayat, R. (2016). Komitmen Penguatan ISPO dalam mewujudkan Industri Kelapa Sawit Berkelanjutan di Indonesia.Jakarta: Sekretariat Komisi ISPO.

Hutabarat, S. (2017). Tantangan keberlanjutan Pekebun Kelapa Sawit Rakyat di Kabupaten Pelalawan, Riau dalam Perubahan Perdagangan Global. Masyarakat Indonesia, 43(1), 47-64.

Indra, S. (2017). Analisis persepsi mahasiswa terhadap niat melakukan Whistleblowing. Jurnal Penelitian Ekonomi dan Bisnis, 3(1), 1-11.

Irianto, H., \& Haryanto, B. (2011). Niat konsumen dalam pembelian makanan organik. Kinerja Jurnal Bisnis dan Ekonomi, 15(1), 73-87.

Jaolis, F. (2011). Profil green consumer Indonesia: Identifikasi segmen dan faktor-faktor yang memengaruhi perilaku pembelian green products. Jurnal Mitra Ekonomi dan Manajemen Bisnis, 2(1), 18-39.

Komisi ISPO. (2014). Perkebunan Kelapa Sawit Berkelanjutan (Indonesian Sustainable Palm Oil/ISPO): Persyaratan untuk Kebun Petani Swadaya (Draf IV). Jakarta: Sekretariat Komisi ISPO, Direktorat Jenderal Perkebunan, Kementerian Pertanian.

Kospa, H. S. (2016). Konsep perkebunan kelapa sawit berkelanjutan. Jurnal Tekno Global, 5(1), 1-10.
Kurniawan, R. (2014). Analisis faktor-faktor yang memengaruhi pendapatan usahatani sawit anggota KUD Mukti Jaya di Kecamatan Sungai Lilin Musi Banyu Asin. SOCIETA, 3(2), 75-82.

Läpple, D., \& Kelley, H. (2013). Understanding the uptake of organic farming: Accounting for heterogeneities among Irish farmers. Ecological Economics, 88, 11-19.

Lestari, E. E., Hutabarat, S., \&Dewi, N. (2015). Studi komparatif perkebunan kelapa sawit rakyat pola plasma dan pola swadaya dalam menghadapi sertifikasi RSPO (Studi Kasus Desa Bukit Lembah Subur Kabupaten Pelalawan Provinsi Riau). Jurnal SOROT, 10(1), 81-98.

Mawardati. (2016). Analisispendapatan usahatani kelapa sawit perkebunan rakyat di Kabupaten Aceh Utara. Jurnal AGRIFO, 1(2), 19-29.

McCullough, M. E., Friedman, H. S., Enders, C. K., \& Martin, L. R. (2009). Does devoutness delay death? Psychological investmen in religion and its association with Longevity in the Terman Sampel. Journal of Personality and Social Psychology, 1(1), 1-17.

Mulyandari, R. S. (2011). Perilaku petani sayuran dalam memanfaatkan teknologi informasi. Jurnal Perpustakaan Pertanian, 20(1), 22-34.

Muttakin, D., Ismail, U., \& Kurniati, S. A. (2014). Faktor-faktor sosial ekonomi yang memengaruhi pendapatan usahatani kelapa sawit pola swadaya di Desa Kepau Jaya Kabupaten Kampar. Jurnal Relevansi, Akurasi dan Tepat waktu, 3(1), 369-378.

Neolaka, A. (2008). Kesadaran Lingkungan. Jakarta: PT Rineka Cipta.

Ngadi, \& Noveria, M. (2017). Keberlanjutan perkebunan kelapa sawit di Indonesia dan prospek pengembangan di kawasan 
perbatasan. Academic Forum on Sustainability I, 43(1), 95-111.

Nurfatriani, F., Ramawati, Sari, G. K., \& Komarudin, H. (2018). Optimalisasi dana sawit dan pengaturan instrumen fiskal penggunaan lahan hutan untuk perkebunan dalam upaya mengurangi deforestasi. Working Paper 238. Retrieved from https://www.cifor.org/publications/pdf_fi les/WPapers/WP238Nurfatriani.pdf.

Nurliza. (2018). Organisasi Petani Sawit Swadaya: Mengatasi Kesenjangan antara Pengetahuan dan Keterampilan Kelapa Sawit Berkelanjutan. Pontianak: IAIN Pontianak Press.

Nurmastiti, A., Suminah,\& Wibowo, A. (2017). Pengaruh karakteristik inovasi dan sistem sosial terhadap adopsi teknologi pengelolaan tanaman terpadu. Jurnal Agritexts , 41(2), 79-92.

Nurofik. (2013). Pengaruh sikap, norma subyektif dan kontrol perilaku pada pengungkapan tanggung jawab sosial. Jurnal Akutansi dan Auditing Indonesia, 17(1), 43-56.

OECD, WTO, \& WG. (2014). Global Value Chains: Challange, Opportunies, and Implications for Policy. Paris: OECD, WTO and World Bank Group.

\section{Peraturan Menteri Pertanian Republik Indonesia. (2015). No. 11/Permentan/OT.140/3/2015. Tentang Sistem Sertifikasi Perkebunan Kelapa Sawit Berkelanjutan Indonesia (Indonesian Sustainable Palm Oil - ISPO). Jakarta: Kementerian pertanian.}

Permatasari, P., Anantanyu, S., \& Dewi, W. S. (2018). Pengaruh tingkat adopsi budidaya padi organik terhadap keberlanjutan budidaya padi organik di Kabupaten Boyolali. Journal of Sustainable Agriculture, 33(2), 153-168.

Prasetia, H. (2017). Optimalisasi pengelolaan berkelanjutan kebun sawit swadaya di
Kabupaten Seruyan, Kalimantan Tengah, Indonesia. Jurnal Tehnik Lingkungan, 3 (1), 39-46.

Pratama, M. Y., Rosnita, \& Yulida, R. (2015). Peran penyuluhan dalam pemberdayaan petani kelapa sawit pola swadaya di Kecamatan Langgam Kabupaten Pelalawan. Jom Faperta, 2(1), 1-15.

Prayoga, K. (2018). Dampak penetrasi teknologi informasi dalam transformasi sistem penyuluhan pertanian di Indonesia. Jurnal Sosial Ekonomi Pertanian, 11(1), 46-59.

Prihandoko, Jahi, A., Gani, D. S., Purnaba, I. G., Adrianto, L., \& Tjitradjaja, I. (2012). Faktor-faktor yang memengaruhi perilaku nelayan artisanal dalam pemanfaatan sumberdaya perikanan di Pantai Utara Provinsi Jawa Barat. Jurnal Penyuluhan, 9(2), 158-173.

Puspitaningsih, O. S., Utami, B. W., \& Wijianto, A. (2016). Partisipasi kelompok tani dalam mendukung program-program pertanian berkelanjutan di Kecamatan Puring, Kabupaten Kebumen (studi komparasi kelompok tani kelas lanjut dan pemula). Journal of Sustainable Agriculture, 31(2), 79-85.

Rokky.S, J., Rosnita, \& Yulida, R. (2015). Peran penyuluhan dalam pemberdayaan petani kelapa sawit pola swadaya di Kecamatan Bagan Sinembah Kabupaten Rokan Hilir. JOM FAPERTA, 2(1), 113.

Sasongko, W. A., Witjaksono, R., \& Harsoyo. (2014). Pengaruh perilaku komunikasi terhadap sikap dan adopsi teknologi budidaya bawang merah di lahan pasir Pantai Kecamatan Sanden Kabupaten Bantul. Jurnal Agro Ekonomi, 24(1), 3543.

Sormin, E. U. (2012). Analisis tingkat pengetahuan petani terhadap manfaat lahan padi sawah di Kabupaten Sedang Bedagai. Journal Social Economic of 
Vicki, Nurliza, Dolorosa, E. : Niat Perilaku Petani Sawit Swadaya ...

Agriculture and Agribusiness, 1(1), 114.

Suharyanto, Rinaldy, J., Arya, N. N., \& Mahaputra, K. (2017 ). Faktor-faktor yang memengaruhi persepsi petani terhadap kebijakan perlindungan lahan pertanian pangan berkelanjutan di Provinsi Bali. Jurnal Pengkajian dan Pengembangan Teknologi Pertanian, 20(2), 111-124.

Suki, N. M. (2013). Young consumer ecological behavior. The effects of environmental knowledge, healty food, and healthy way of life the moderation of gender. Environmental Quality: an International journal, 6(24), 726-737.

Suryandari, N. K., Suprapti, N. W., \& Sukaatmadja, I. P. (2016). Aplikasi theory of planned behavior dalam menjelaskan perilaku ekologis generasi Y di Kota Denpasar. Jurnal Manajemen, Strategi Bisnis dan Kewirausahaan, 10(1), 31-41.

Venkatesh, V., \& Davis, F. D. (2000). A theoretical extension of the technology acceptance model: Four longitudinal field studies. Management Science, 46(2), 186-204 .

Wilson, B. (2012). Manajemen Sumber Daya Manusia. Jakarta: Erlangga.

Yuwono, D. M. (2013). Pengarusutamaan gender dalam pembangunan pertanian: Kasus pada pelaksanaan Program FEATI di Kabupaten Magelang. Jurnal Sosial Ekonomi Pertanian dan Agribisnis, 10(1), 140-147. 